Article

\title{
Land Cover Change in the Abuja City-Region, Nigeria: Integrating GIS and Remotely Sensed Data to Support Land Use Planning
}

\author{
Evidence Chinedu Enoguanbhor ${ }^{1,2, *}$, Florian Gollnow ${ }^{3} \mathbb{D}^{-}$, Jonas Ostergaard Nielsen ${ }^{1,2}$, \\ Tobia Lakes ${ }^{1,2}$ and Blake Byron Walker ${ }^{1}$ (D) \\ 1 Institute of Geography (Applied Geoinformation Science Lab), Humboldt University of Berlin, \\ Unter den Linden 6, 10099 Berlin, Germany; jonas.ostergaard.nielsen@hu-berlin.de (J.O.N.); \\ tobia.lakes@geo.hu-berlin.de (T.L.); walkerbl@geo.hu-berlin.de (B.B.W.) \\ 2 Integrative Research Institute on Transformations of Human-Environmental Systems, Humboldt University \\ of Berlin, Unter den Linden 6, 10099 Berlin, Germany \\ 3 National Socio-Environmental Synthesis Center (SESYNC), University of Maryland, 1 Park Place, Suite 300, \\ Annapolis, MD 21401, USA; fgollnow@sesync.org \\ * Correspondence: evidence.chinedu.enoguanbhor@geo.hu-berlin.de; Tel.: +49-1521-911-7475
}

Received: 17 January 2019; Accepted: 26 February 2019; Published: 2 March 2019

\begin{abstract}
Rapid urban expansion is a significant contributor to land cover change and poses a challenge to environmental sustainability, particularly in less developed countries. Insufficient data about urban expansion hinders effective land use planning. Therefore, a high need to collect, process, and disseminate land cover data exists. This study focuses on urban land cover change detection using Geographic Information Systems and remote sensing methods to produce baseline information in support for land use planning. We applied a supervised classification of land cover of LANDSAT data from 1987, 2002, and 2017. We mapped land cover transitions from 1987 to 2017 and computed the net land cover change during this time. Finally, we analyzed the mismatches between the past and current urban land cover and land use plans and quantified the non-urban development area lost to urban/built-up. Our results indicated an increase in urban/built-up and bare land cover types, while vegetation land cover decreased. We observed mismatches between past/current land cover and the existing land use plan. By providing detailed insights into mismatches between the regional land use plan and unregulated urban expansion, this study provides important information for a critical debate on the role and effectiveness of land use planning for environmental sustainability and sustainable urban development, particularly in less developed countries.
\end{abstract}

Keywords: change detection; urban expansion; urban planning; regional planning; environmental sustainability; Sub-Saharan Africa

\section{Introduction}

Global urban growth/expansion continues to rapidly increase [1-3], causing significant impacts on land and environmental dynamics at the regional and local scales [4-6]. The associated land use/cover changes [7-12] pose a great challenge to environmental sustainability [13] and sustainable urban development [6]. In this context, environmental sustainability is defined as the condition that allows human society to meet their current needs without compromising the current and future health of natural ecosystems [14]. Sustainable urban development thereby relies on designing urban areas with consideration given to consumption (e.g., energy) and pollutions (e.g., waste, water, air, and soil) [15], together with social, economic, and cultural considerations of creating a functional urban environment for current and future generations. 
Environmental sustainability and sustainable urban development can be improved through informed land use planning. Uncoordinated, unenforced, or non-existent land use planning may result in haphazard development [16] and excess deterioration of the built and natural environments. In less developed countries (and particularly in Sub-Saharan Africa), rapid urban expansion and growth of informal settlements challenge current efforts for sustainable land use planning [17]. Land use planning, which is the process of allocating land to different uses in order to balance social, economic and environmental objectives [18], focuses on the spatiality and geographies of socioeconomic and ecological factors to optimize the use of space while minimizing conflict [19]. Applied land use planning varies widely, but the general process includes preparation (defining the goal and objectives), data collection and analysis, plan formulation, negotiation and decision-making, implementation, and monitoring and updating [19]. According to Metternicht [20], land use planning processes can be carried out at different scales (e.g., urban, regional, national). At the regional scale, the process of land use planning aims to resolve conflicts between national goals and local interests by balancing different purposes such as new settlements, protected areas, intensive agriculture, and animal husbandry.

In less developed countries, including Nigeria, land use planning processes are greatly inhibited by insufficient data availability [21-23]. This is also the case for Abuja, one of the fastest growing cities in Sub-Saharan Africa [24]. The potential of Geographic Information Systems (GIS) and remote sensing (RS) tools to offer new insights into land use planning and urban development is yet to be fully tapped. While previous research efforts in less developed countries have successfully applied GIS and RS techniques and data to quantify land use/cover change, the literature is yet to explore how these approaches directly relate to land use planning. In Abuja, Nigeria, Mahmoud et al. [25] report an increase in urban land cover to the detriment of bare land. They argue that the spatial pattern of urban expansion in Abuja is based on the master plan and exhibits sprawl towards surrounding satellite towns. Owoeye and Ibitoye [8] show urban expansion at the expense of vegetation in Akure, Nigeria. They suggested that the master plan of the city is in dire need of revision and a comprehensive regional land use plan should be prepared to address the problems of urban expansion but did not conduct a comparison between planned and actual land cover. Nkeki [26] shows how urban expansion affected agricultural and forest land use/cover in Benin City, Nigeria, concluding that vital planning information for urban planners and public decision-making bodies can potentially be extracted from the findings. Akintunde, Adzandeh, and Fabiyi [27] show that urban land increased, while non-urban land decreased in Jos, Nigeria. They argue that urban development did not conform to the recent master plan in Jos. While comparing urban growth in three African cities (Bamako, Cairo, and Nairobi), Hou, Estoque, and Murayama [28] show an increase in urban expansion corresponding to a decrease in bare land, arguing that there is unplanned urban expansion in rapidly growing African cities. Similar results have been found in cities outside Africa. For example, Barrera and Henríquez [12] observed an increase in urban growth and a decrease in urban vegetation in three cities in Chile, suggesting that the vegetation can and should be preserved using urban planning and design. Liu et al. [29] observed cropland losses due to urban expansion in the past four decades in China, although no reference to urban land use planning rendered it impossible to quantify how much of the development was haphazard in nature.

In Sub-Saharan Africa, no previous study has assessed land cover change to analyze the mismatches between urban expansion trend and land use plans. By quantifying the differences between proposed land uses and actual development, this study seeks to address this gap, supporting more sustainable urban planning and development in the Abuja city-region.

We integrate GIS and open access RS data to examine spatial trends of urban land cover change in Abuja, Nigeria between 1987 and 2017; in doing so, this study provides baseline information in support for informed land use planning. Specifically, we sought to: (1) visualize and quantify the spatial pattern of land cover types for 1987, 2002, and 2017; (2) quantify the land cover transitions between urban/built-up and vegetation, bare land, and water; (3) compute the net change of land cover types between 1987, 2002, and 2017, and; (4) quantify the mismatches between urban/built-up and the urban 
and regional land use plans to offer new insights into the past and current urban dynamics. This paper thereby provides objective information to inform a critical debate on the role and effectiveness of land use planning for environmental sustainability and sustainable urban development in less developed countries. As such, our paper contributes to current research on urban land cover change, particularly urban expansion and its environmental problems that could be useful to support land use planning in Sub-Saharan Africa and other less developed countries across the globe.

\section{Materials and Methods}

\subsection{Study Area}

This study focuses on Abuja, one of the fastest growing cities in Sub-Saharan Africa [30]. As shown in Figure 1, the study area is a part of the Nigerian Federal Capital Territory (FCT) and comprises the Federal Capital City (FCC) and other surrounding settlements. The total area of the study area is approximately $1994 \mathrm{~km}^{2}$. It covers the major parts of two local government areas of FCT, which include Abuja Municipal and Bwari Local Government Areas. It extends into Gwagwalada and Kuje Local Government Areas of FCT in the southern part of the city-region [25].

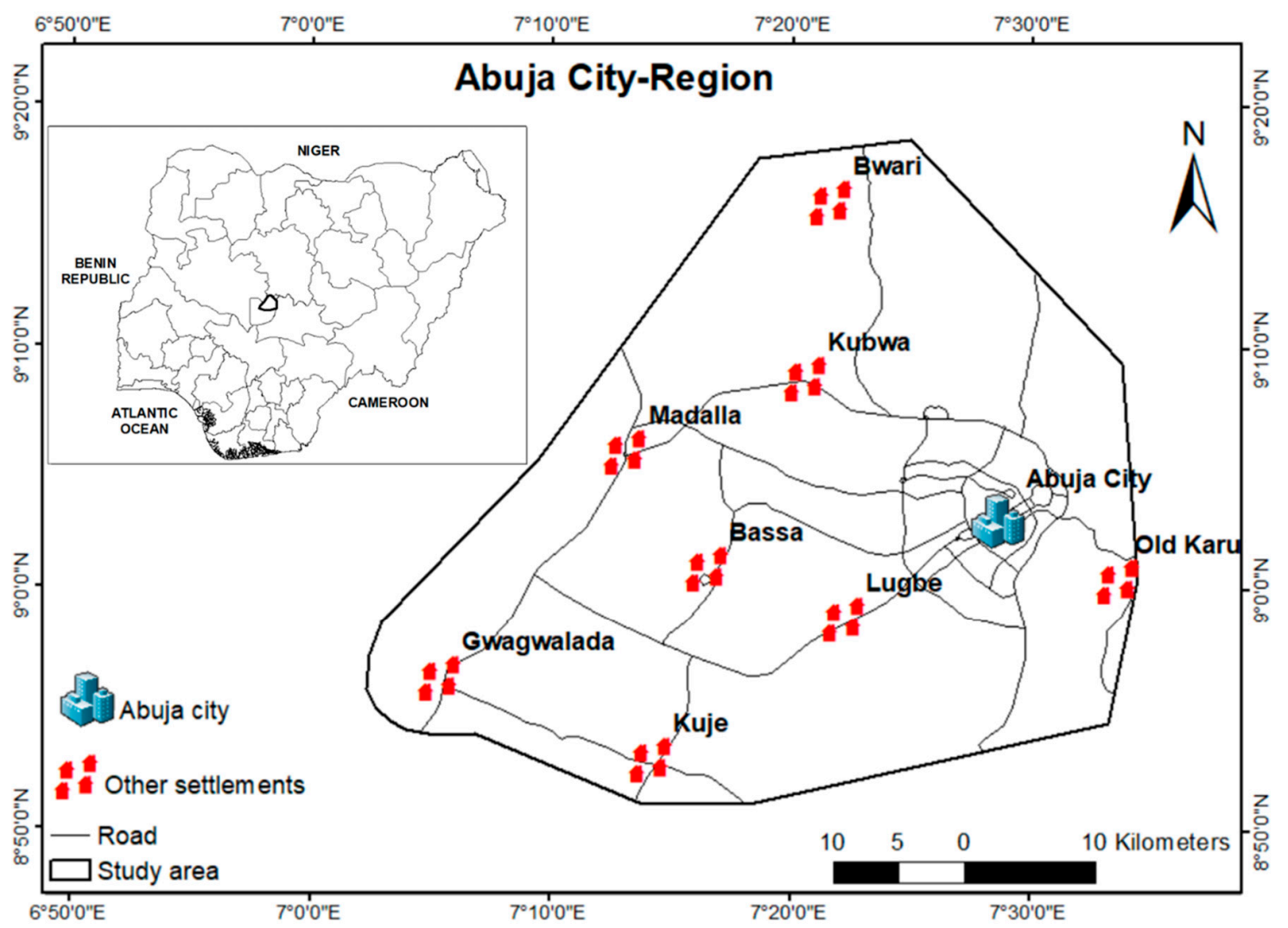

Figure 1. Map of the Abuja city-region showing the locations of Abuja city and the surrounding settlements.

Abuja was declared the new capital city of Nigeria in 1976, due to overpopulation, shortage of land for urban expansion, distortion of the master plan, and traffic congestion, in the formal capital Lagos [30,31]. By contrast, Abuja featured availability of space for urban development, a central location to provide almost equal access to the different ethnic groups across Nigeria, and an ethnically neutral territory [32]. The FCT Abuja was carved out from four states [30]. The seat of government was officially relocated to FCT Abuja in 1991 [33] and since then the region has witnessed a high rate of urban growth [34]. The population of FCT Abuja was 1,406.239 million in 2006 [35,36]. Based on the 2006 population, we estimate the population of FCT Abuja to be 3,770,376 million in 2017. This 
population explosion and the accompanying sprawl has led to pressure on the surrounding natural resources causing loss of other land uses in the region [37].

In 1979, the Abuja master plan was prepared to comprise regional and urban land use plans [30]. The regional land use plan covers the FCT Abuja, while that of the urban land use plan was limited to the city, Abuja, and was divided into four phases [38]. The four development phases included 5, 15, 19, and 29 districts, respectively [30]. Phase 1 included the central district (planned for the governmental seat of power and the Central Business District), and four other residential districts [39]. Additional urban land use plans for the satellite settlements were separately designed [39]. However, through field surveys, we observed that the urban land use plans for the satellite settlements have not been implemented in most areas. These areas are currently characterized by informal settlements (Figure 2). The purpose of the Abuja land use plans included the designation of areas for urban land uses, the preservation of the natural environment, improved accessibility of all areas [40], coordination of land use [32], etc. Monitoring of urban expansion and updating of land use plans are challenged by rapid urban growth and especially by the development and expansion of informal settlements in peri-urban/satellite settlements in the city-region. In Abuja city, urban land uses expanded from a few development districts to create some urban extensions [37]. Vegetation, which is another important land cover in the Abuja city-region, is similar to that of other parts of FCT Abuja. The vegetation is categorized under the West African ecoregion of Guinean Forest-Savannah mosaic [41]. Due to the location of the Abuja city-region in the northern part of FCT Abuja, the area is dominated by the savannah vegetation, which is characterized by deciduous trees that are scattered among grasses [42].

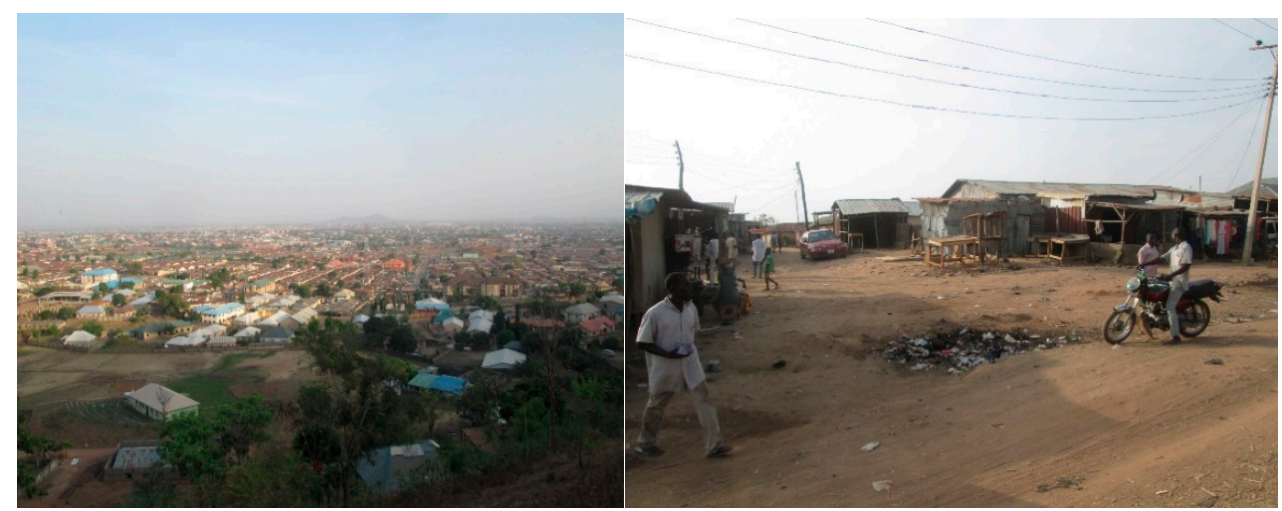

(a)

(b)

Figure 2. Urban expansion by informal settlements (a) Old Karu and (b) Bassa.

\subsection{Data Collection}

We collected remotely sensed data that were captured in 1987 from Landsat 4 satellite (Thematic Mapper), 2002 from Landsat 7 satellite (Enhanced Thematic Mapper plus), and 2017 from Landsat 8 satellite (Operational Land Image). The spatial resolution for all the satellite images is $30 \mathrm{~m}$ (Table 1). The data were obtained from the United States Geological Survey (USGS) Earth Explorer service, an online, openly-accessible platform for acquiring remotely sensed imagery [43].

Table 1. Summary of remotely sensed data description.

\begin{tabular}{cccccc}
\hline Landsat Series & Sensor & Spatial Resolution & No: of Bands & Date of Acquisition & Sources \\
\hline Landsat 4 & TM & $30 \mathrm{~m}$ & 7 & $21 / 12 / 1987$ & USGS \\
Landsat 7 & ETM+ & $30 \mathrm{~m}$ & 9 & $30 / 12 / 2002$ & USGS \\
Landsat 8 & OLI & $30 \mathrm{~m}$ & 11 & $14 / 02 / 2017$ & USGS \\
\hline
\end{tabular}


Additionally, we used satellite imagery accessed via Google Earth in 2017, the regional land use plan of FCT Abuja [44], and the 2011 FCC Abuja revised land use plan phases 1, 2, and 3 [45]. The regional land use plan was collected from the Abuja Geographic Information System (AGIS), while the urban land use plan was collected from the Department of Urban and Regional Planning (DURP) in Abuja. A field trip was conducted from 19 February to 27 March 2018, during which urban and regional land use plans were collected, and informal interviews and discussion were held regarding the urban and regional planning processes, de facto urban development, and environmental challenges.

\subsection{Data Analysis}

We performed spatial analyses using ArcGIS (version 4.1) and TerrSet (version 9.3), including land cover classification, accuracy assessments, transition mapping, change detection, and cartographic overlays. We applied a supervised classification method to derive land cover types. Supervised classification is a process whereby samples of pixels from a satellite image are carefully selected in locations, where each pixel's true land cover type is known (e.g., following field observation). The spectral signatures of these known pixels are then analyzed to estimate and assign information classes to unknown pixels [46]. This method enables the analyst to have control over the assignment of different pixel classes based on known information about the study area [46]. The supervised classification algorithm used in this study is the maximum likelihood classifier, which relies on the probability that different pixels belong to different classes [47] and assigns pixels to the class with the highest probability [48]. The maximum likelihood algorithm was used as it has been demonstrated in the literature to produce high-accuracy results for land cover classification [49]. The land cover classes were categorized into the most frequently occurring classes in the satellite imagery: urban/built-up, vegetation, bare land, and water (Table 2).

Table 2. Categories of land cover classes.

\begin{tabular}{cc}
\hline Land Cover Classes & Description of Land Cover \\
\hline Urban/built-up & Elements of urban/rural settlements such as buildings, roads, etc. \\
Vegetation & Forest vegetation: Tall trees that form canopy as healthy vegetation. \\
Bare land & Savannah vegetation: Isolated short trees mixed with grasses. \\
Water & All other surfaces such as open space with bare soil, rocks. \\
Lakes and other water bodies.
\end{tabular}

We performed accuracy assessments of the land cover classification using GIS and Google Earth. We sampled referenced points using a stratified random sampling approach method, which is a probability sampling applicable to assess class-specific accuracy [50] and which allows for selecting the number of points relatively proportional to the sizes of each land cover class. This is to ensure that each land cover class is properly represented by referenced points in order to reduce bias in the accuracy assessments. We used a total of 500 points for validation on Google Earth satellite images for 1987, 2002, and 2017. We randomly selected 200, 150, 100, and 50 points from land cover types for vegetation, bare land, urban/built-up, and water, respectively. We calculated the user (errors of commission) and producer (errors of omission) accuracies for each land cover class for 1987, 2002, and 2017, as well as overall accuracy and Kappa coefficients. The formulae for accuracy assessments are expressed as:

$$
\mathrm{UA}=\frac{\mathrm{CR}}{\mathrm{TR}}
$$

where UA is user accuracy, CR is the number of correctly classified pixels in each row category. TR is the total number of classified pixels in the same row category.

$$
\mathrm{PA}=\frac{\mathrm{CC}}{\mathrm{TC}}
$$


where PA is the producer accuracy, CC is the number of correctly classified pixels in each column category. TC is the total number of classified pixels in the same column category.

$$
\mathrm{OA}=\frac{\mathrm{CD}}{\mathrm{TP}}
$$

where $\mathrm{OA}$ is the overall accuracy, $\mathrm{CD}$ is the number of correctly classified pixels in diagonal. TP is the total number of referenced points.

$$
\mathrm{KC}=\frac{(\mathrm{TP} * \mathrm{CD})-\sum(\mathrm{TC} * \mathrm{TR})}{\mathrm{TP}^{2}-\sum(\mathrm{TC} * \mathrm{TR})}
$$

where KC is the kappa coefficient.

After the accuracy assessments, we quantified the land cover transition through tabulation and transition mapping in GIS [51]. The essence of the transition mapping was to calculate the transition change between urban/built-up area and other land cover types. We computed the net change detection between 1987, 2002 and 2017 using the differential method of post-classification comparison of specific land cover types [52]. We performed the analysis by simple arithmetic of subtracting the calculated area and the percentage of formal land cover classes from the latter.

To offer new insights into the past and current urban dynamics, we analyzed the mismatches between urban/built-up and the urban and regional land use plans by geo-referencing, geo-processing, and digitizing the official plans. We digitized the locations of dense informal settlements from Google Earth and reclassified and extracted urban/built-up from land cover maps for 1987, 2002 and 2017. We performed an overlay analysis of the variables to visualize the urban expansion trends on the regional land use plan and urban planned area. Finally, we quantified the non-urban development areas including land uses designated for nature conservation, intensive agriculture, and animal husbandry lost to urban/built-up in 1987, 2002, and 2017 and calculated their annual change (degraded) rate (ACR). The formula we applied to calculate the non-urban development areas lost to urban/built-up is expressed as:

$$
\mathrm{ANL}=\mathrm{TLC}-\mathrm{LCD}
$$

where ANL is the area of non-urban lost to urban/built-up, TLC is the total urban/built-up land cover of the City-Region, and LCD is the total urban/built-up land cover in the area designated for urban development. The formula we applied to calculate the percentage of the area of non-urban lost to urban/built-up is expressed as:

$$
\frac{\mathrm{ANL}}{\mathrm{AND}} * \frac{100}{1}
$$

where AND is the total area for non-urban development. The formula we applied to calculate the ACR is expressed as:

$$
\mathrm{ACR}=\frac{\mathrm{LA}_{2}-\mathrm{LA}_{1}}{\mathrm{~T}}
$$

where $\mathrm{LA}_{2}$ is the latter area of non-urban lost to urban/built-up, $\mathrm{LA}_{1}$ is the initial area of non-urban lost to urban/built-up, and $\mathrm{T}$ is the time interval between $\mathrm{LA}_{1}$ and $\mathrm{LA}_{2}$ observations. Figure 3 shows the schematic diagram of materials and methods used in this study. 


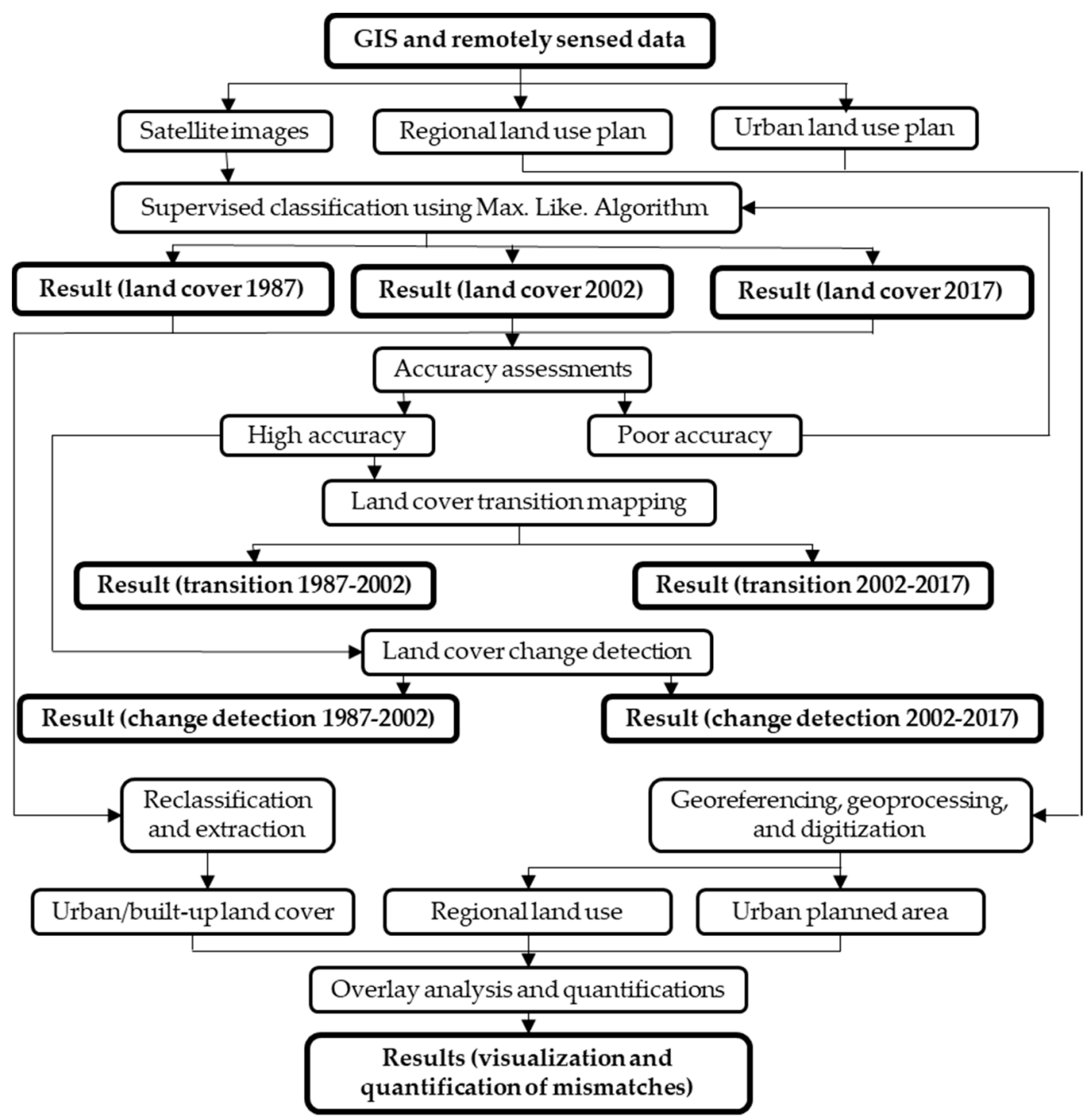

Figure 3. Methods for land cover change detection.

\section{Results}

We visualized and quantified the spatial pattern of land cover types for 1987, 2002, and 2017 by performing the supervised classification of land cover. Our results (Figure 4 and Table 3) show that in 1987 the urban/built-up areas were mostly distributed in the eastern part of the city-region. The urban/built-up class covered $1.8 \%$ of the total area, vegetation covered $73.0 \%$, bare land covered $24.7 \%$, and water covered $0.5 \%$. In 2002 (Figure 4 and Table 3), the pattern of distribution indicates that the urban/built-up areas were mostly concentrated in the eastern part of the area, covering $10.0 \%$ in the Abuja city-region. Vegetation covered $63.3 \%$, bare land covered $26.2 \%$, while water covered $0.5 \%$. In 2017, the results (Figure 4 and Table 3) show that urban/built-up cover is expanding from east to south and south-west, and covered $19.3 \%$. Vegetation covered $50.8 \%$, while bare land and water covered $29.5 \%$ and $0.4 \%$, respectively.

Table 3. Calculated area of land cover of Abuja in 1987, 2002, and 2017.

\begin{tabular}{|c|c|c|c|}
\hline \multirow{2}{*}{$\begin{array}{c}\text { Land Cover } \\
\text { Classes }\end{array}$} & 1987 & 2002 & 2017 \\
\hline & Area $\mathrm{km}^{2}$ ( $\%$ of Study Area) & Area $\mathrm{km}^{2}$ ( $\%$ of Study Area) & Area $\mathrm{km}^{2}$ (\% of Study Area) \\
\hline Urban/built-up & $36.8(1.8 \%)$ & $198.8(10.0 \%)$ & $385.4(19.3 \%)$ \\
\hline Bare land & $491.9(24.7 \%)$ & $522.1(26.2 \%)$ & $588.6(29.5 \%)$ \\
\hline Water & $9.3(0.5 \%)$ & $9.6(0.5 \%)$ & $7.7(0.4 \%)$ \\
\hline
\end{tabular}




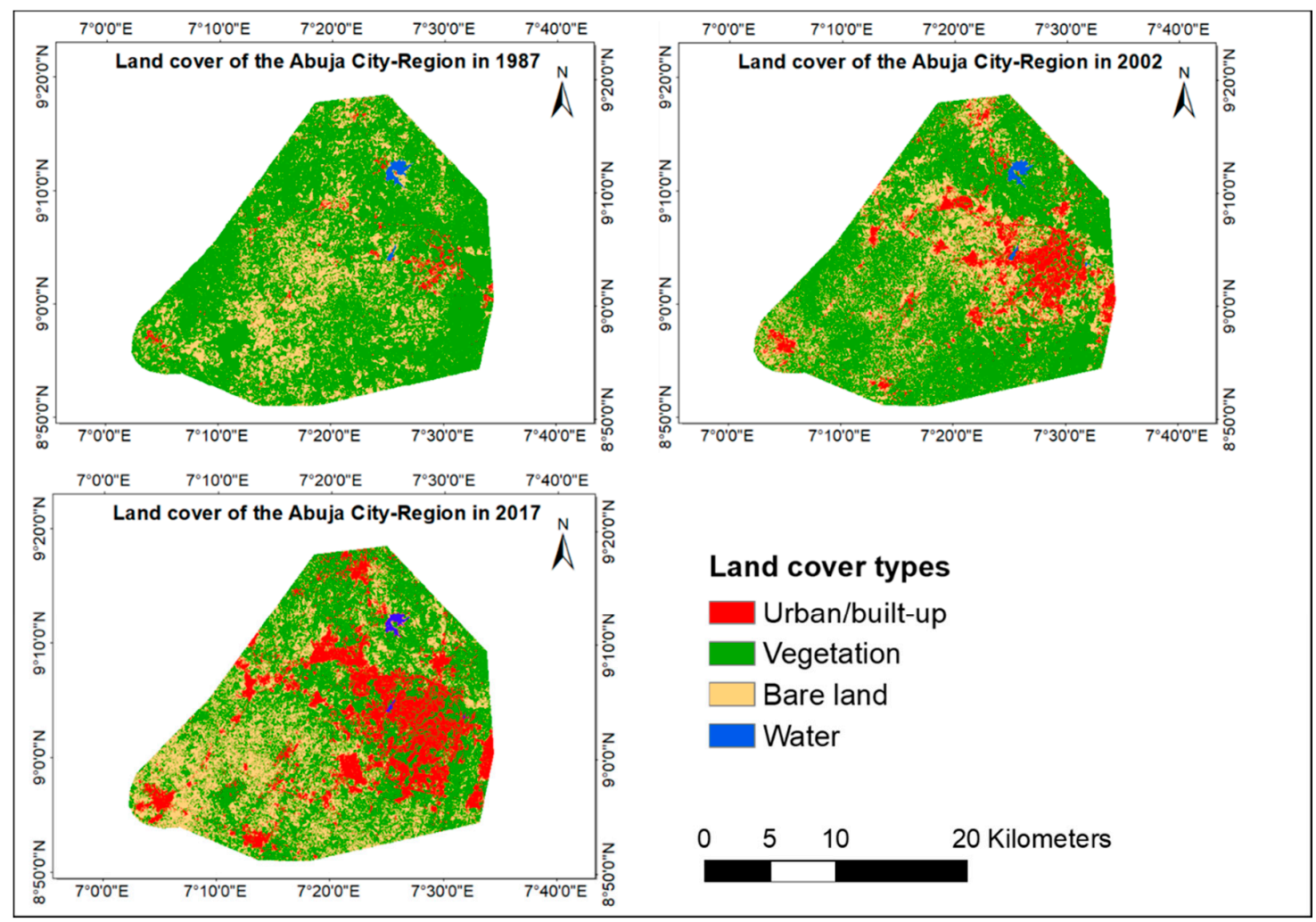

Figure 4. Land cover of Abuja city-region in 1987, 2002, and 2017.

We calculated the user accuracy (UA), producer accuracy (PA), overall accuracy (OA), and Kappa coefficients (KC) of land cover classification for 1987, 2002, and 2017 (Table 4). The OA and KC show that the accuracy assessments of land cover classifications for 1987, 2002, and 2017 are high.

Table 4. Accuracy assessments of land cover classification for 1987, 2002, and 2017.

\begin{tabular}{|c|c|c|c|c|c|c|c|c|c|c|c|c|}
\hline \multirow{2}{*}{$\begin{array}{l}\text { Land Cover } \\
\text { Classes }\end{array}$} & \multicolumn{4}{|c|}{1987} & \multicolumn{4}{|c|}{2002} & \multicolumn{4}{|c|}{2017} \\
\hline & UA & PA & OA & KC & UA & PA & OA & KC & UA & PA & OA & KC \\
\hline Urban/built-up & $91 \%$ & $94.8 \%$ & & & $88 \%$ & $87.8 \%$ & & & $96 \%$ & $85.3 \%$ & & \\
\hline Vegetation & $97.5 \%$ & $97.5 \%$ & & & $94.5 \%$ & $95.9 \%$ & & & $95 \%$ & $98.4 \%$ & & \\
\hline Bare land & $93.3 \%$ & $88.6 \%$ & $94 \%$ & 0.91 & $94.7 \%$ & $89.3 \%$ & $92.6 \%$ & 0.89 & $94.7 \%$ & $94 \%$ & $94 \%$ & 0.91 \\
\hline Water & $88 \%$ & $95.6 \%$ & & & $88 \%$ & $95.7 \%$ & & & $84 \%$ & $97.7 \%$ & & \\
\hline
\end{tabular}

We quantified the land cover transitions between urban/built-up and vegetation, bare land, and water through transition mapping. The result (Figure 5) shows that from 1987 to 2002, an area of $113 \mathrm{~km}^{2}$ of vegetation transitioned into urban/built-up area. $60.5 \mathrm{~km}^{2}$ transitioned from bare land to urban/built-up, and water did not change. However, some urban/built-up land cover also transitioned into vegetation and bare land by $4.7 \mathrm{~km}^{2}$ and $4.5 \mathrm{~km}^{2}$, respectively. Urban/built-up did not change into water, as expected. Vegetation features the largest land cover transition into urban/built-up areas from 1987 to 2002, followed by bare land. From 2002 to 2017, the result (Figure 6) shows that an area of $117.3 \mathrm{~km}^{2}$ of vegetation transitioned into the urban/built-up area. $117.2 \mathrm{~km}^{2}$ and $1.0 \mathrm{~km}^{2}$ transitioned respectively, from bare land and water into the urban/built-up area. However, urban/built-up also transitioned into vegetation and bare land by $38.6 \mathrm{~km}^{2}$ and $13.7 \mathrm{~km}^{2}$, respectively. Vegetation and bare land have almost equal land cover transitions into urban/built-up area from 2002 to 2017. 


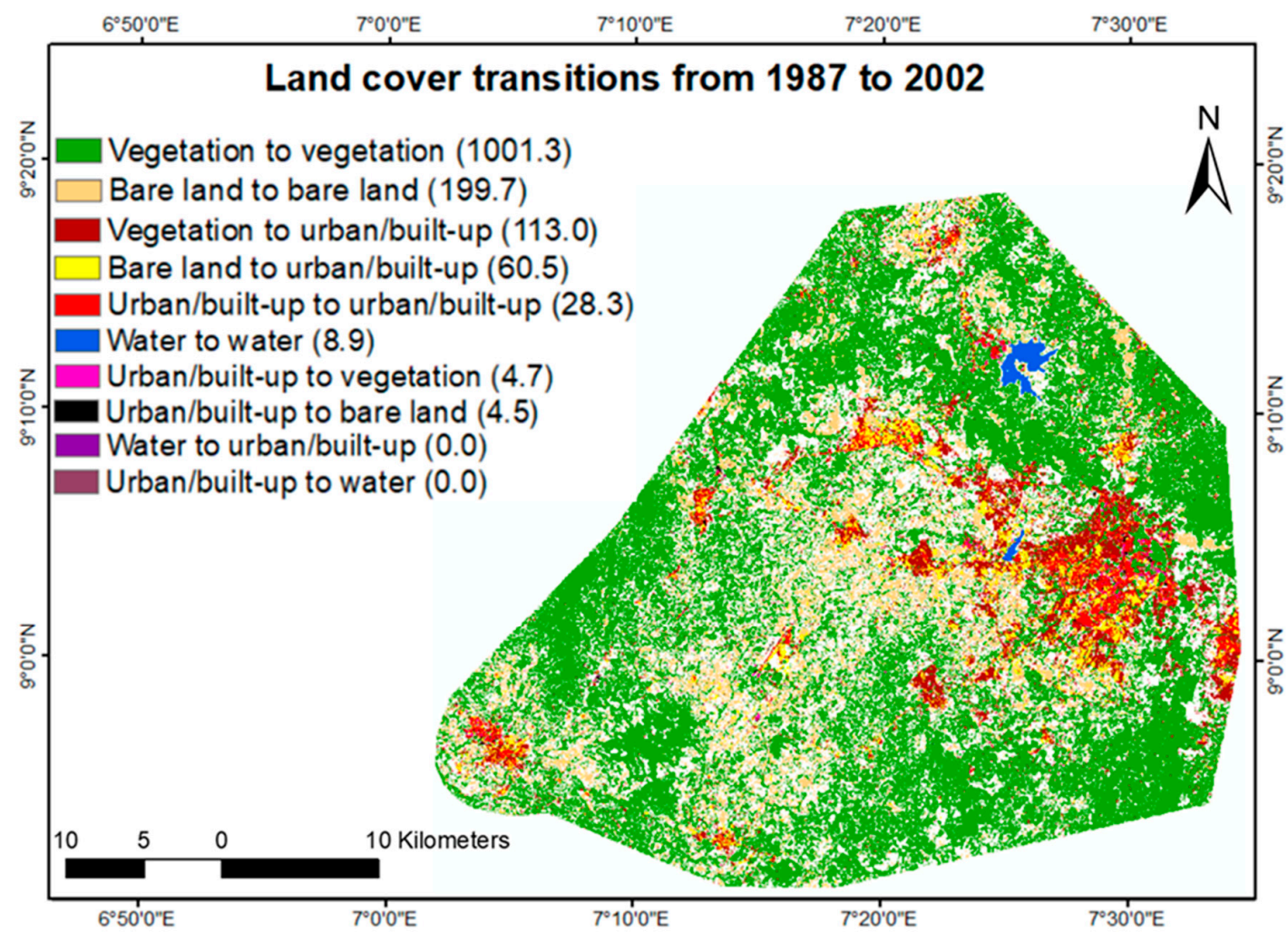

Figure 5. Abuja land cover transition from 1987 to 2002, with transitioned land area shown in parentheses in $\mathrm{km}^{2}$.

$6^{\circ} 50^{\prime} 0$ "E $7^{\circ} 0^{\prime} 0^{\prime \prime E}$

$7^{\circ} 10^{\prime} 0^{\prime \prime E}$

$7^{\circ} 20^{\prime} 0^{\prime \prime} \mathrm{E}$

$7^{\circ} 30$ '0"E

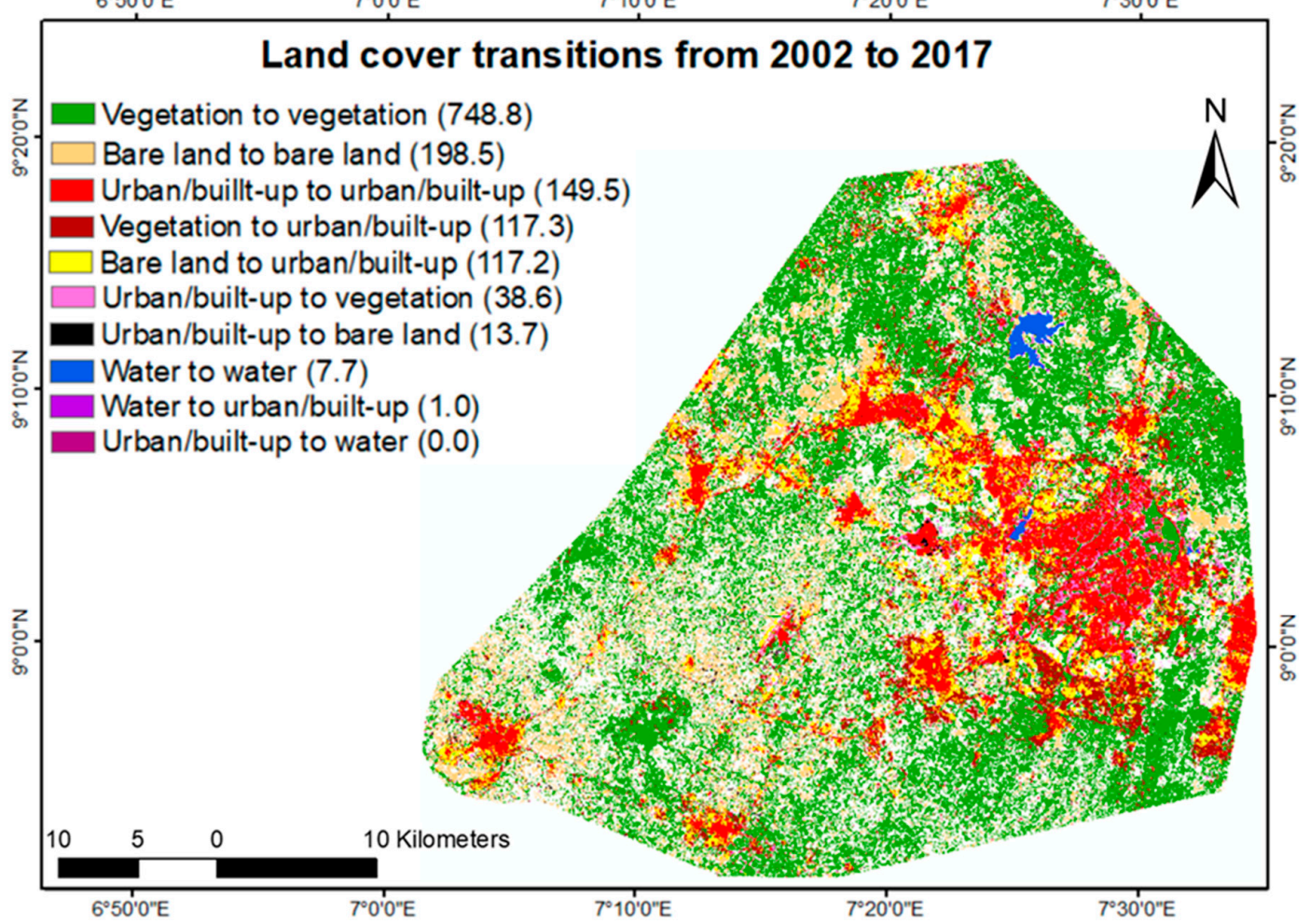

Figure 6. Abuja land cover transition from 2002 to 2017, with transitioned land area shown in parentheses in $\mathrm{km}^{2}$. 
We computed the net land cover change from 1987 to 2002 and from 2002 to 2017 (Figure 7). Our result showed that from 1987 to 2002, urban/built-up increased by $162 \mathrm{~km}^{2}(8.2 \%)$, while bare land increased by $30.2 \mathrm{~km}^{2}(1.5 \%)$. There was no increase or decrease in water. The only land cover that decreased was vegetation, with the highest observed change at $193.1 \mathrm{~km}^{2}(9.7 \%)$. Second to the highest land cover class is urban/built-up, which from 2002 to 2017 increased by $186.6 \mathrm{~km}^{2}(9.3 \%)$, while bare land increased by $66.1 \mathrm{~km}^{2}(3.3 \%)$. Vegetation decreased by $250.6 \mathrm{~km}^{2}(12.5 \%)$ and water decreased by $1.9 \mathrm{~km}^{2}(0.1 \%)$. The highest land cover class that is changing is vegetation followed by urban/built-up.

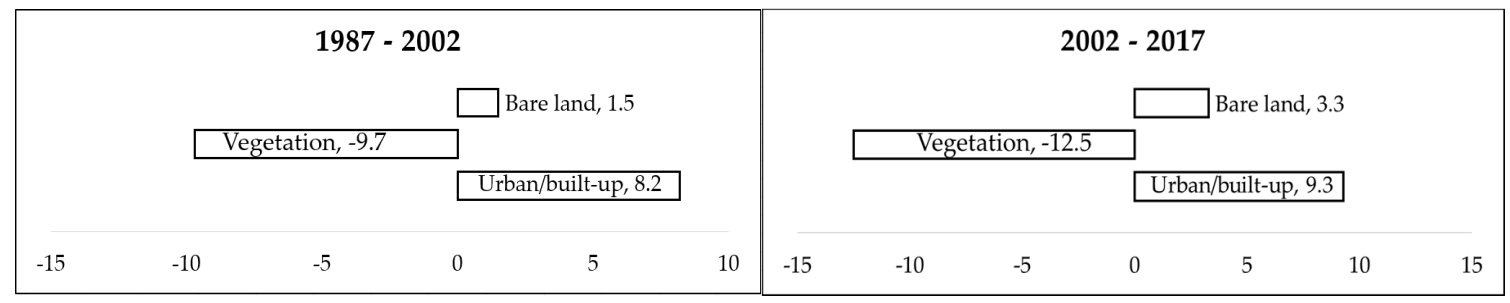

(a)

(b)

Figure 7. Percentage change detection of Abuja land cover from (a) 1987 to 2002 and (b) 2002 to 2017.

We analyzed mismatches between urban/built-up, the land use plans, and the distribution of dense informal settlements (Figures 8 and 9). The regional land use plan indicated that the areas designated for urban development are primarily within Abuja city, with urban extensions in the peri-urban/satellite settlements. In the southern part of the city-region, the area designated for urban development for Abuja city extends beyond the boundary of the city-region.

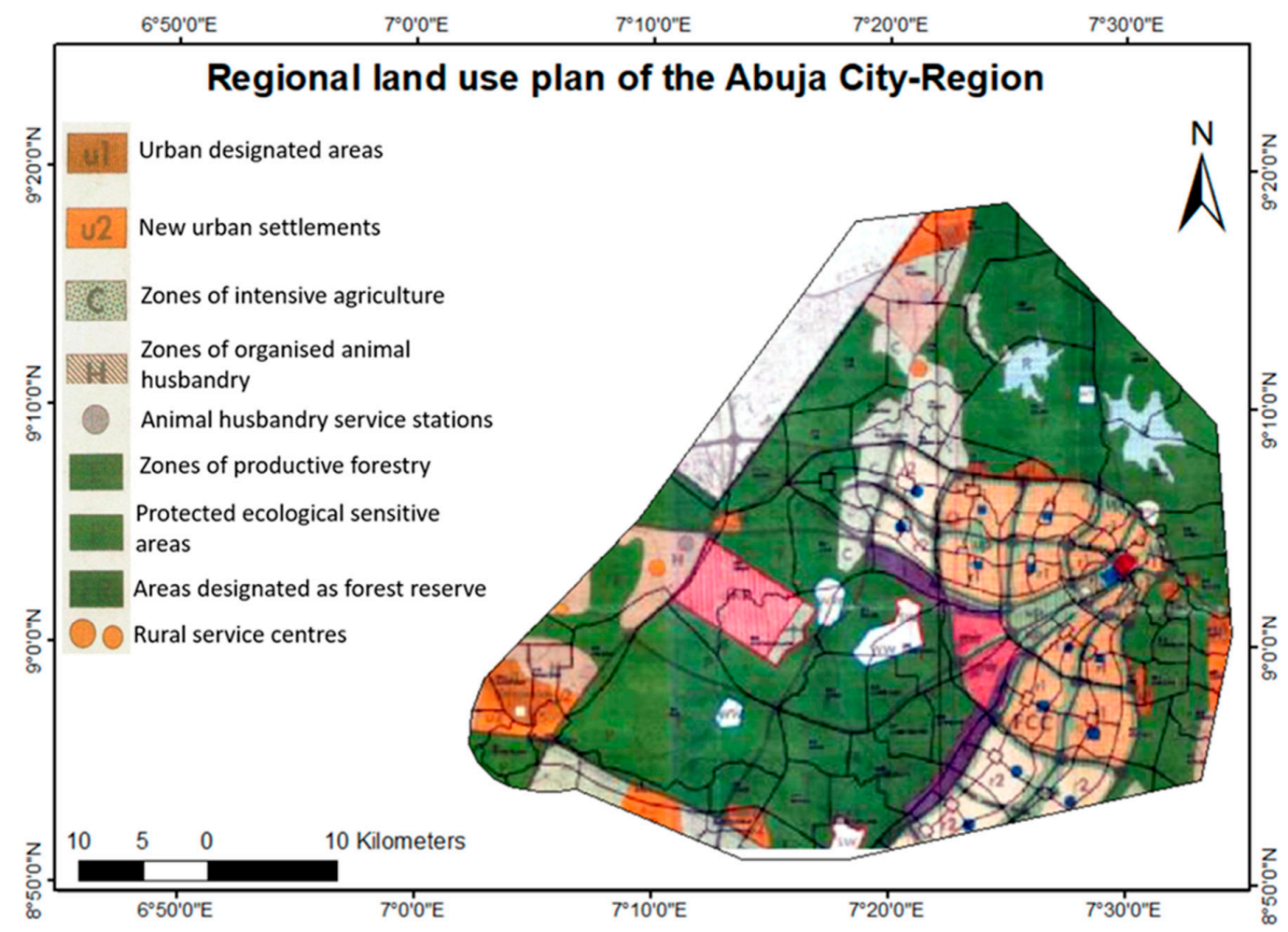

Figure 8. The regional land use plan of the Abuja city-region.

Past and current urban developments are mostly concentrated in Abuja city, with more space for urban development found in the southern part of the city. However, urban land uses are also expanding into areas designated for non-urban development (Figure 10). Our results in Table 5 indicate that the total area of non-urban development in the city-region is approximately $555.25 \mathrm{~km}^{2}$. Urban/built-up 
gradually expanded into the non-urban development areas, which lost $11.65 \mathrm{~km}^{2}(0.8 \%), 73.58 \mathrm{~km}^{2}$ (5.1\%), and $179.57 \mathrm{~km}^{2}(13.7 \%)$ to urban/built-up in 1987, 2002, and 2017, respectively (Table 5 and Figure 11). From 1987 to 2002 and from 2002 to 2017, the ACR of non-urban development areas was $4.13 \mathrm{~km}^{2}$ and $7.07 \mathrm{~km}^{2}$ per year, which converted to urban/built-up land uses, respectively.

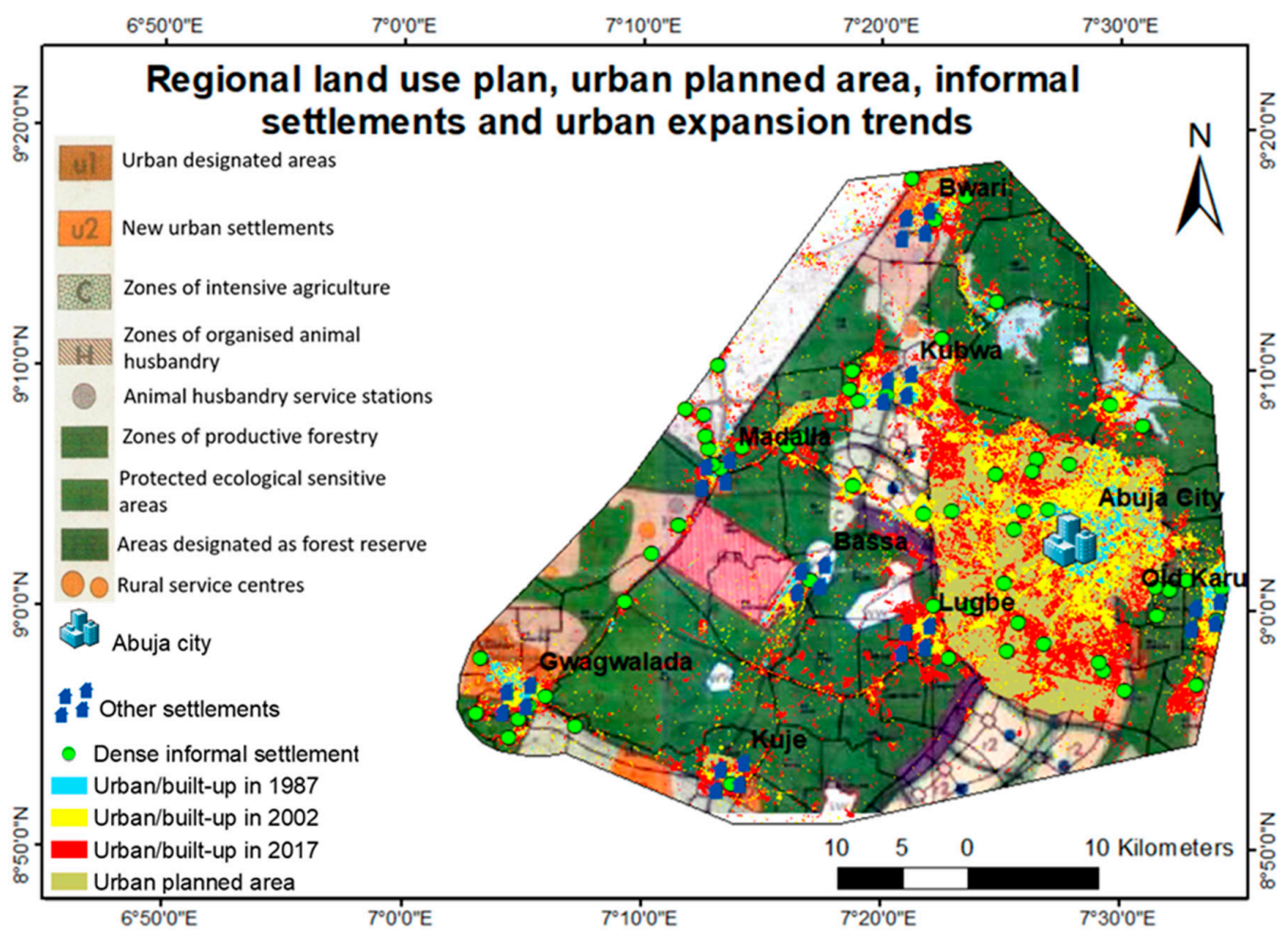

Figure 9. The regional land use plan, with urban expansion trends overlaid for visual comparison.

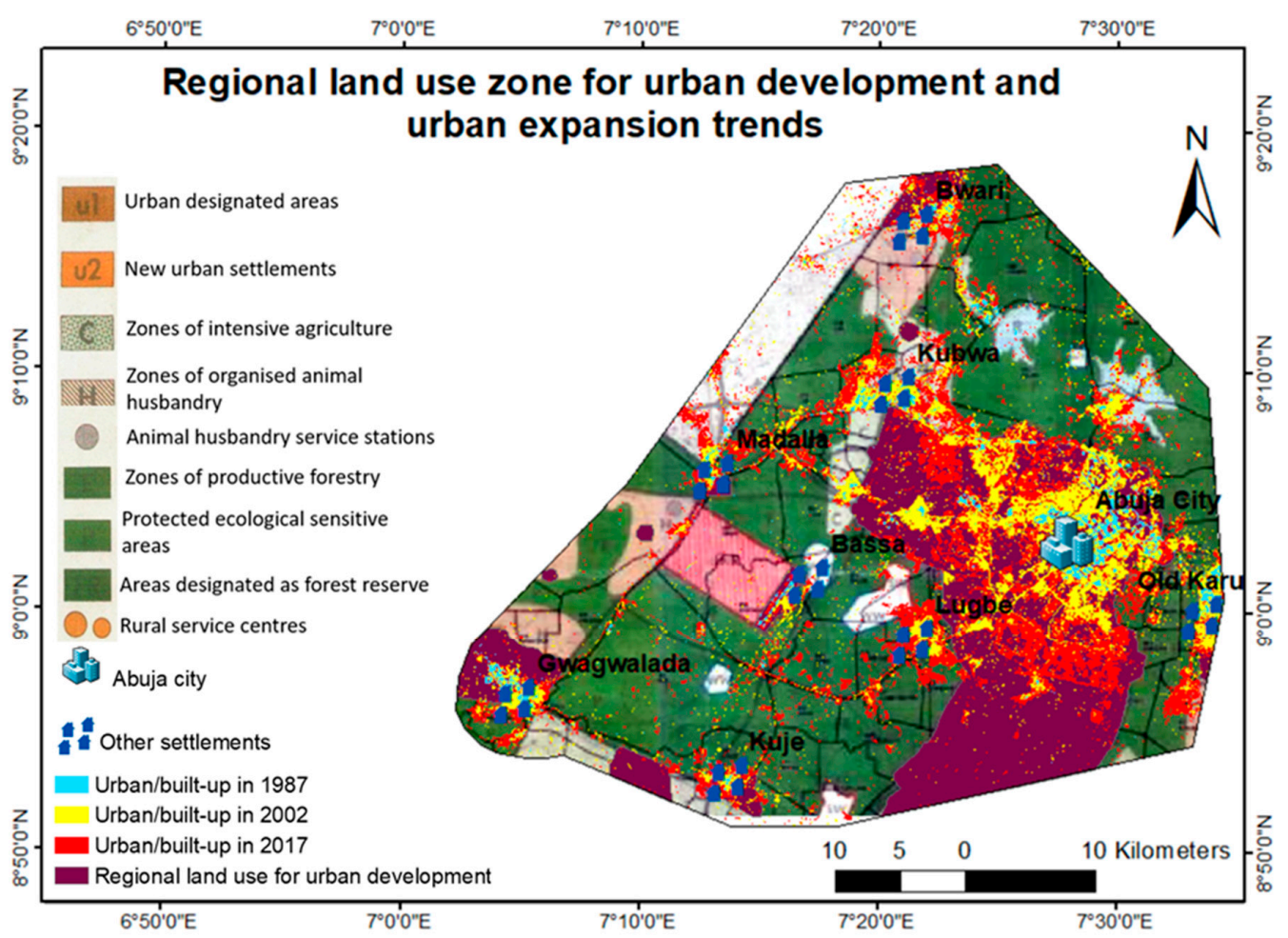

Figure 10. The regional land use for urban development and urban expansion into other land uses. 
Table 5. Calculated area planned for urban development and urban/built-up in other land uses.

\begin{tabular}{|c|c|c|c|c|}
\hline Years & \multicolumn{2}{|c|}{$\begin{array}{l}\text { Regional Planned Area for } \\
\text { Urban Development in } \mathbf{k m}^{2}\end{array}$} & $\begin{array}{l}\text { Urban/Built-up } \\
\text { Area in } \text { km }^{2}\end{array}$ & $\begin{array}{l}\text { Urban/Built-up in Non-urban } \\
\text { Development Area in } \text { km }^{2}\end{array}$ \\
\hline 1987 & \multicolumn{2}{|r|}{555.25} & 36.8 & 11.65 \\
\hline 2002 & \multicolumn{2}{|r|}{555.25} & 198.8 & 73.58 \\
\hline 2017 & \multicolumn{2}{|r|}{555.25} & 385.4 & 179.57 \\
\hline \multicolumn{5}{|c|}{ Urban expansion and non-urban area lost to urban/built-up } \\
\hline \multicolumn{5}{|c|}{$25.0 \%$} \\
\hline \multicolumn{5}{|c|}{$15.0 \%$} \\
\hline \multicolumn{5}{|c|}{$10.0 \%$} \\
\hline \multicolumn{5}{|c|}{$5.0 \%$} \\
\hline \multicolumn{2}{|r|}{$0.0 \%$} & 1987 & 2002 & 2017 \\
\hline —Urban & It-up & $1.8 \%$ & $10.0 \%$ & $19.3 \%$ \\
\hline $\begin{array}{r}\text { Non-c } \\
\text { ur }\end{array}$ & $\begin{array}{l}\text { area lost to } \\
\text { built-up }\end{array}$ & $0.8 \%$ & $5.1 \%$ & $13.7 \%$ \\
\hline
\end{tabular}

Figure 11. Percentage of non-urban land area lost to urban/built-up and urban expansion trends.

Our results in Figures 12 and 13 show that the past and current urban expansion encroached into the proposed land use for intensive agriculture, animal husbandry and protected areas. The protected area lost to urban/built-up in 1987, 2002, and 2017 are $0.92 \mathrm{~km}^{2}, 6.84 \mathrm{~km}^{2}$, and $16.65 \mathrm{~km}^{2}$, respectively. In 1987, 2002, and 2017, the proposed land use for intensive agriculture lost $3.73 \mathrm{~km}^{2}, 18.98 \mathrm{~km}^{2}$, and $34.91 \mathrm{~km}^{2}$, respectively, while that of animal husbandry lost $0.16 \mathrm{~km}^{2}, 1.16 \mathrm{~km}^{2}$, and $3.59 \mathrm{~km}^{2}$ to urban/built-up. From 1987 to 2002 and from 2002 to 2017, the ACR of the protected areas lost to urban/built-up is $0.39 \mathrm{~km}^{2}$ and $0.65 \mathrm{~km}^{2}$ per year. The ACR of the proposed land use for intensive agriculture lost to urban/built-up is $1.02 \mathrm{~km}^{2}$ from 1987 to 2002 and $1.06 \mathrm{~km}^{2}$ from 2002 to 2017 per year, while that of animal husbandry is $0.07 \mathrm{~km}^{2}$ and $0.16 \mathrm{~km}^{2}$ from 1987 to 2002 and from 2002 to 2017 .

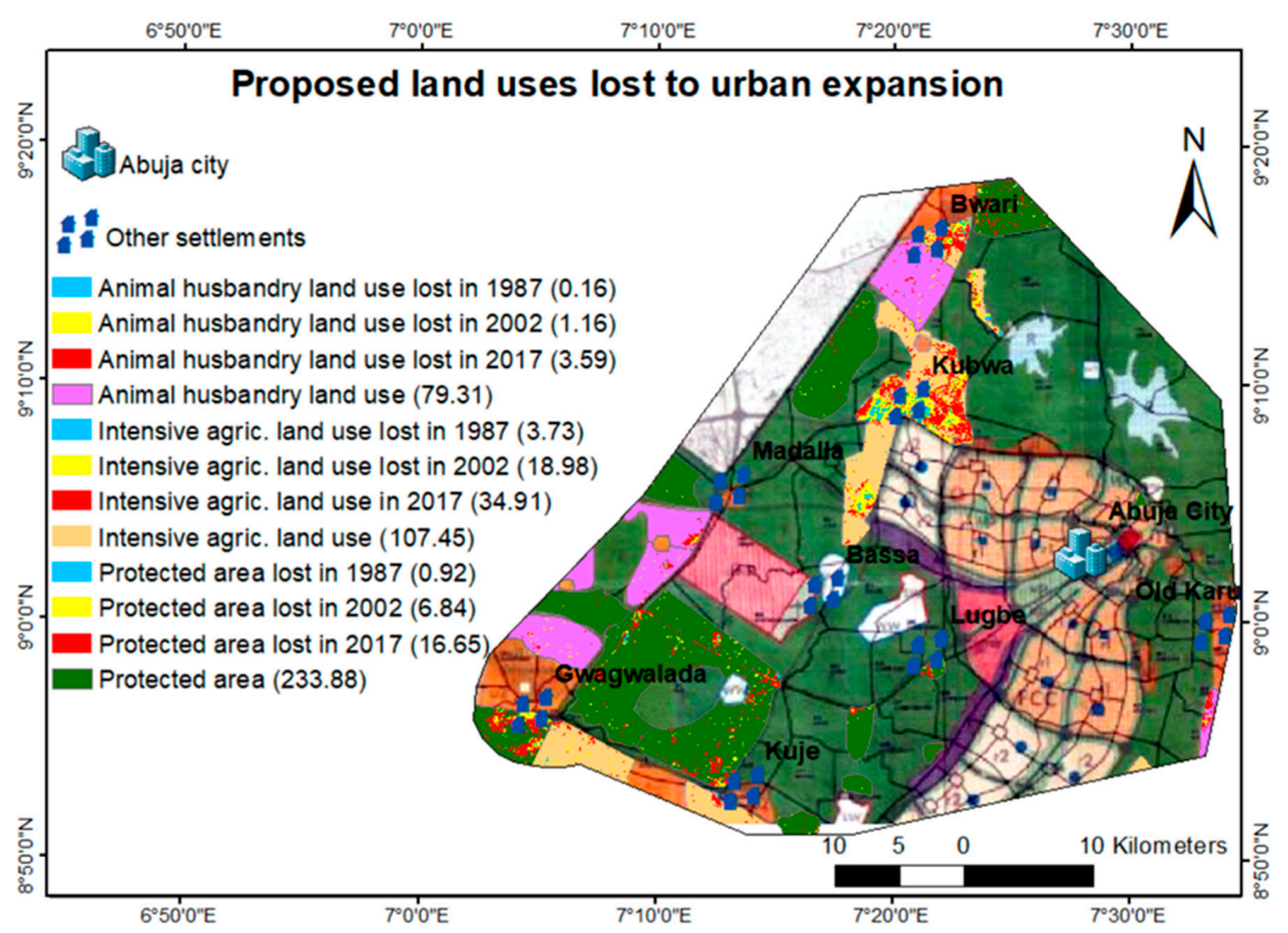

Figure 12. The encroachment of urban expansion into various proposed land uses in $\mathrm{km}^{2}$. 


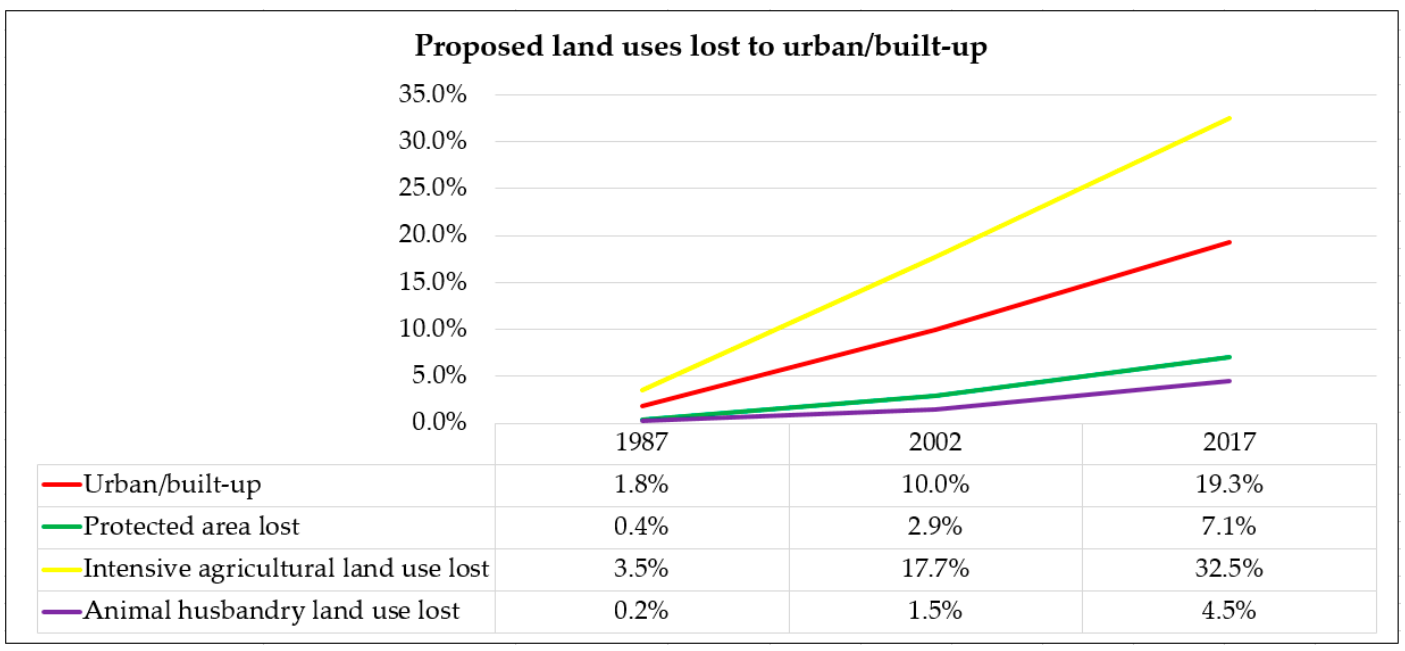

Figure 13. Percentage of proposed land uses lost to urban/built-up and urban expansion trends.

\section{Discussion}

This study provides the first instance of a comprehensive analysis of urban land cover change in relation to land use planning in the Abuja city-region. We integrated GIS and freely available RS data to examine the spatial trends of urban and other land cover changes in Abuja, from 1987 to 2017 and were, therefore, able to provide baseline information that can be used to support land use planning.

Our results highlight large mismatches between the regional land use plan and the observed urban land cover, indicating an uncontrolled and rapid urban expansion. This result indicates gaps between planned land use developments and actual urban expansion, similar to those observed by Shen et al. [53] for urban expansion in China, who underscored that urban expansion occurred often in an uncontrolled manner and in conflict to proposed and existing land use plans, impeding efforts for a more sustainable urban expansion. Our study showed that the area designated for urban development was larger than the total area of the past and current urban land cover (Figure 10 and Table 5). The urban expansion might have been more sustainable if it were steered towards the areas proposed for urban development. Figure 8 showed that the regional land use plan proposed Lugbe as one of the areas for productive forestry and forest reserve. However, as indicated in Figure 12, urban expansion did not stop at the proposed borders of urban development areas. Between 2002 and 2017, urban areas expanded continuously into Lugbe. In the city-region, various land uses designated for nature conservation, intensive agriculture, animal husbandry that were lost to urban/built-up have increased in recent decades (Figures 12 and 13). Built-up land coverage in 1987 was relatively low at $1.8 \%$ (Table 3 ) when the region primarily comprised of a few, isolated settlements. A large expansion of urban/ built-up area could be identified until 2002 (10\%), which increased to 19.3\% in 2017 (Figure 4 and Table 3). The transition mapping results indicated rapid urban expansion at the expense of vegetation cover. This result differs from those of Mahmoud et al. [25], who reported rapid urban expansion at the expense of bare land in Abuja. However, the results coincide with several previous studies such as Akpu et al. [7], Owoeye and Ibitoye [8], and Fanan, Isa, and Olarewaju [11], who observed urban expansion at the expense of vegetation cover in their various study areas. The reduction of vegetation cover as indicated by our results also corresponds with similar studies, such as Mahmoud et al. [25], Owoeye and Ibitoye [8], and Barrera and Henríquez [12], and Hassan [54], all of which highlight a large loss of vegetated area due to urban expansion in developing regions. Parallel to the expansion of urban areas, we also observed an increase in bare lands, adding to an even more rapid reduction of vegetation within the region. Despite the high degree at which bare land was converted into urban/built-up between 2002 and 2017 (Figure 6), our result showed an increase of bare land (Table 3), similar to Fanan, Isa, and Olarewaju [11]. This result contradicts that of Mahmoud et al. [25], who reported a decrease in bare land in Abuja. In other African cities, decreases in bare land during periods of urban 
expansion have been observed by Hou, Estoque, and Murayama [28]. Our observed increase in bare land may be due to rapid increases in food and wood demands, in turn driving agricultural expansion and deforestation. Further field observation and interviews with locals will enable us to explore this question directly in subsequent research.

In less-developed countries, informal settlements are primarily home to low-income earners and are characterized by deteriorating housing [55]. In Sub-Saharan Africa, such neighborhoods comprise the majority of urban growth [56-58] and are mostly found around the peri-urban space [59] and satellite towns [30]. We observed similar spatial trends of urban expansion in relation to the locations of dense informal settlements. As reported by Trefon [59] and Goodfellow [60], urban growth in the peri-urban areas of Sub-Saharan African cities is often haphazard and chaotic. Such urban growth is characterized by rapid population growth, pressure on urban land tenure systems [61], insufficient infrastructure, and severe environmental degradation [59]. We observed similar urban development in peri-urban/satellite settlements of the Abuja city-region (Figure 2a,b).

An important implication of these findings addresses urban expansion beyond the scope of urban land use plans, underscoring the necessity to address informal settlements and their effects on the implementation of land use plans in Abuja. The Abuja urban planning efforts are not administratively allowed to address proposed urban/built-up by the regional land use plan (Figure 10) and at the satellite settlements, the urban plans have not been implemented in most areas. This lack of urban planning may be a key contributing factor to the development of informal settlements, particularly in peri-urban/satellite settlements (Figure 9) and is a serious challenge for sustainable urban development. Furthermore, the expansion of urban land use into protected areas has led to deforestation, habitat loss, and has increased the risk of biodiversity loss. The loss of land designated for intensive agriculture is also certain to have direct negative impacts on local food availability and soil health, both of which are vital elements of urban and environmental sustainability.

However, this paper demonstrates that some existing and potential problems associated with land cover change and urban development can be identified using GIS and freely available RS data. Of particular importance at this stage are the mismatches between urban expansion trends and various land uses designated for non-urban development by the regional land use plan. As such, our study contributes to the current literature on urban expansion in relation to land use planning in less-developed countries. Additionally, the urban expansion at the expense of vegetation is associated with local urban planning efforts and lack of implementation in peri-urban/surrounding settlements. Moving forward, such spatial information is necessary to inform decision-makers in land use planning, particularly by enabling decision-makers to make direct comparisons between actual urban and regional land use plans with other alternative plans, prior to their attempted implementation.

This study was limited by the unavailability of high-resolution spatial data. We used RS data with a $30 \mathrm{~m}$ spatial resolution data because they are freely available for multiple points in time. Using such data makes it challenging to differentiate some sub-categories of urban land use such as residential, industrial, and mixed land uses, as well as identifying dense informal settlements without the need for direct field observation. However, the availability of free and long-term data allows for possible monitoring of land cover processes and a transfer to other areas with limited financial resources and personnel. The unavailability of Phase 4 of the urban land use plan (currently under revision) prevented us from incorporating this phase into our study. The land cover maps and change trajectories presented within this manuscript might be one helpful additional source of information for the revision of the plans, once they are made available.

As a result of our analysis, we put forth the following recommendations. Urban planning and its implementation should not be limited to Abuja city but rather expanded to include peri-urban and other surrounding settlements in the city-region. This would help urban land use planning efforts to encompass regional land use, which is intricately tied to potentially sustainable urban development. The administrative challenges preventing the successful implementation of land use plans should be monitored in more detail and directly addressed. Spatial information about land cover change 
and urban expansion can and should be produced at low-cost using GIS and freely available RS data to support land use planning. By disseminating such spatial information, important steps towards strategic action (such as land use policies and enforcement) can be taken. Finally, there is a pressing need for further research addressing the disconnect between spatial data, land use planning, and the implementation of land use plans in developing countries.

\section{Conclusions}

We applied GIS and RS data to analyze past and current land cover change in relation to land use planning. Our results indicate an increase in urban/built-up and bare land cover types, corresponding to a decrease in vegetation cover from 1987 to 2017. The largest observed transition featured urban growth in place of vegetation. The highest observed net changes in land cover types were vegetation, followed by urban/built-up, and bare land. Comparison of actual land cover changes against the city and regional plans indicated large mismatches. Perhaps most alarming is the recent loss of land designated for protected areas, intensive agriculture, and animal husbandry, now replaced with unplanned and haphazard urban development. This is most evident in the peri-urban/satellite settlements, where the loss of natural ecosystems and agricultural resources is certain to pose future challenges to environmental sustainability and sustainable urban development in the city-region.

Overall, this study provides evidence that integrating GIS and open access RS data constitutes a useful approach for the provision of baseline spatial information. Such spatial information is crucial for informed land use planning to improve environmental sustainability and sustainable urban development in the city-regions found in both Sub-Saharan Africa and less-developed countries worldwide.

Author Contributions: All authors contributed to this study. In particular, E.C.E. carried out the design, analysis, and interpretation of the work, while T.L., J.O.N., B.B.W., and F.G. reviewed the work and contributed to improving the manuscript.

Acknowledgments: The authors are grateful to Paul+Maria Kremer Stiftung for the PhD scholarship awarded to the first author. F.G. was supported by the National Socio-Environmental Synthesis Center (SESYNC) under funding received from the National Science Foundation DBI-1639145. The authors are also grateful to the USGS and Landsat programme for making the remotely sensed data openly available and accessible. The authors acknowledge AGIS (Abuja Geographic Information Systems) and DURP (Department of Urban and Regional Planning), Abuja for making the regional and urban land use plans available for the study.

Conflicts of Interest: The authors declare that there are no conflicts of interest.

\section{References}

1. Nor, A.N.M.; Corstannje, R.; Harris, J.A.; Brewer, T. Impact of rapid urban expansion on green space structure. Ecol. Indic. 2017, 81, 274-284. [CrossRef]

2. Zhou, Y.; Li, X.; Asrar, G.R.; Smith, S.J; Imhoff, M. A global record of annual urban dynamics (1992-2013) from nighttime lights. Remote Sens. Environ. 2018, 219, 206-220. [CrossRef]

3. Angel, S.; Parent, J.; Civco, D.L.; Blei, A.; Potere, D. The dimensions of global urban expansion: Estimates and projections for all countries, 2000-2050. Prog. Plan. 2011, 75, 53-107. [CrossRef]

4. Vasenev, V.I.; Stoorvogal, J.J.; Leemans, R.; Valentini, R.; Hajiaghayeva, R.A. Projection of urban expansion and related changes in soil carbon stocks in the Moscow Region. J. Clean. Prod. 2018, 170, 902-914. [CrossRef]

5. Kukkonen, M.O.; Muhammad, M.J.; Käyhkö, N.; Luoto, M. Urban expansion in Zanzibar City, Tanzania: Analyzing quantity, spatial patterns and effects of alternative planning approaches. Land Use Policy 2018, 71, 554-565. [CrossRef]

6. Tiitu, M. Expansion of the built-up areas in Finnish city regions-The approach of travel-related urban zones. Appl. Geogr. 2018, 101, 1-13. [CrossRef]

7. Akpu, B.; Tanko, A.I.; Jeb, D.N.; Dogo, B. Geospatial Analysis of Urban Expansion and Its Impact on Vegetation Cover in Kaduna Metropolis, Nigeria. AJEE 2017, 3, 31149. [CrossRef]

8. Owoeye, J.O.; Ibitoye, O.A. Analysis of Akure Urban Land Use Change Detection from Remote Imagery Perspective. Urban Stud. Res. 2016, 2016, 4673019. [CrossRef] 
9. Gibson, J.; Boe-Gibson, G.; Stichbury, G. Urban land expansion in India 1992-2012. Food Pol. 2015, 56, 100-113. [CrossRef]

10. Quan, B.; Bai, Y.; Romkens, M.J.M.; Chang, K.; Song, H.; Guo, T.; Lei, S. Urban land expansion in Quanzhou City, China, 1995-2010. Habitat Int. 2015, 48, 131-139. [CrossRef]

11. Fanan, U.; Dlama, K.I.; Oluseyi, I.O. Urban expansion and vegetal cover loss in and around Nigeria's Federal Capital City. J. Ecol. Nat. Environ. 2011, 3, 1-10. Available online: https:/ /academicjournals.org/journal/ JENE/article-abstract/CE94A3B5892 (accessed on 20 December 2017).

12. Barrera, F.D.L.; Henríquez, C. Vegetation cover change in growing urban agglomerations in Chile. Ecol. Indic. 2017, 81, 265-273. [CrossRef]

13. Nwokoro, I.I.; Dekolo, S.O. Land use change and environmental sustainability: The case of Lagos Metropolis. In Sustainable City VII: Urban Regeneration and Sustainability; Pacetti, M., Passerini, G., Brebbia, C.A., Latini, G., Eds.; WIT Press: Southampton, UK, 2012; Volume 155, pp. 157-167.

14. Morelli, J. Environmental Sustainability: A Definition for Environmental Professionals. J. Environ. Sustain. 2011, 1, 19-27. [CrossRef]

15. Abdullahi, S.; Pradhan, B. Sustainable Urban Development. In Spatial Modeling and Assessment of Urban Form Analysis of Urban Growth: From Sprawl to Compact Using Geospatial Data, 1st ed.; Pradhan, B., Ed.; Springer International Publishing AG: Basel, Switzerland, 2017; pp. 17-34. ISBN 978-3-319-54216-4.

16. Yin, J. Urban Planning for Dummies, 3rd ed.; John Wiley \& Sons Canada Ltd.: Mississauga, ON, Canada, 2012.

17. UN-Habitat. State of the World's Cities 2010/2011: Bridging the Urban Divide; Earthscan Publishing for a Sustainable Future: London, UK, 2008.

18. Phillips, P.M.; João, E. Land use planning and the ecosystem approach: An evaluation of case study planning frameworks against the Malawi Principles. Land Use Policy 2017, 68, 460-480. [CrossRef]

19. BMZ. Land Use Planning: Concept, Tools and Applications; GIZ: Eschborn, Germany, 2012.

20. Metternicht, G. Global Land Outlook Working Paper: Land Use Planning; UNCCD (United Nations Convention to Combat Desertification): Sydney, Australia, 2017.

21. Schug, F.; Okujeni, A.; Hauer, J.; Hostert, P.; Nielsen, J.O.; van der Linden, S.F. Mapping pattern of urban development in Ouagadougou, Burkina Faso, using machine learning regression modeling with bi-seasonal Landsat time series. Remote Sens. Environ. 2018, 210, 217-228. [CrossRef]

22. Aribigbola, A. Constraints to Urban Land Use Planning and Management in Nigeria: Evidence from Ondo State. J. Environ. 2013, 2, 66-73. Available online: https:/ /www.scientific-journals.co.uk/web_documents/ 4020311_constraints_urban_land_use.pdf (accessed on 21 December 2017).

23. Potts, D. Challenging the Myths of Urban Dynamics in Sub-Saharan Africa: The Evidence from Nigeria. World Dev. 2012, 40, 1382-1393. [CrossRef]

24. Africa in Focus Figure of the Week: Africa is Home to the 10 Fastest Growing Cities in The World. Available online: https: / / www.brookings.edu/blog/africa-in-focus/2018/10/05/figure-of-the-week-africa-is-hometo-fastest-growing-cities-in-the-world/ (accessed on 5 October 2018).

25. Mahmoud, M.I.; Duker, A.; Conrad, C.; Thiel, M.; Ahmad, H.S. Analysis of Settlement Expansion and Urban Growth Modelling Using Geoinformation for Assessing Potential Impacts of Urbanization on Climate in Abuja City, Nigeria. Remote Sens. 2016, 8, 220. [CrossRef]

26. Nkeki, F.N. Spatio-temporal analysis of land use transition and urban growth characterization in Benin metropolitan region, Nigeria. Remote Sens. Appl. Soc. Environ. 2016, 4, 119-137. [CrossRef]

27. Akintunde, J.A.; Adzandeh, E.A.; Fabiyi, O.O. Spatio-temporal pattern of urban growth in Jos Metropolis, Nigeria. Remote Sens. Appl. Soc. Environ. 2016, 4, 44-54. [CrossRef]

28. Hou, H.; Estoque, R.C.; Murayama, Y. Spatiotemporal analysis of urban growth in three African capital cities: A grid-cell-based analysis using remote sensing data. J. Afr. Earth Sci. 2016, 123, 381-391. [CrossRef]

29. Liu, F.; Zhang, Z.; Zhao, X.; Wang, X.; Zuo, L.; Wen, Q.; Yi, L.; Xu, J.; Hu, S.; Liu, B. Chinese cropland losses due to urban expansion in the past four decades. Sci. Total Environ. 2019, 650, 847-857. [CrossRef] [PubMed]

30. Abubakar, I.R. Abuja city profile. Cities 2014, 41, 81-91. [CrossRef]

31. FMITI (Federal Ministry of Industry, Trade and Investment). Resettlement and Social Audit: Abuja Technology Village Project; FMITI: Abuja, Nigeria, 2015.

32. COHRE (The Centre on Housing Rights and Evictions); SERAC (Social and Economic Rights Action Centre). The Myth of Abuja Master Plan: Forced Evictions as Urban Planning in Abuja, Nigeria; COHRE: Geneva, Switzerland, 2008; ISBN 978-92-95004-43-6. 
33. Idoko, M.A.; Bisong, F.E. Application of Geo-Information for Evaluation of Land Use Change: A Case Study of Federal Capital Territory-Abuja. Environ. Res. J. 2010, 4, 140-144. [CrossRef]

34. Omole, F.K. Land use violations: Implication for sustainable development, the case study of the Federal Capital City Abuja, Nigeria. Curr. Res. J. Soc. Sci. 2009, 1, 31-37. Available online: https:/ /maxwellsci.com/ jp /abstract.php?jid=CRJSS\&no=3\&abs=6 (accessed on 22 December 2017).

35. City Population: Federal Capital Territory, Nigeria. Available online: https://www.citypopulation.de/php/ nigeria-admin.php?adm1id=NGA015 (accessed on 22 December 2017).

36. DEPRS (Department of Economic Planning and Research Statistics). 2015 Statistical Year Book; National Bureau of Statistics: Abuja, Nigeria, 2015.

37. Ujoh, F.; Kwabe, I.D.; Ifatimehin, O.O. Understanding urban sprawl in the Federal Capital City, Abuja: Towards sustainable urbanization in Nigeria. J. Geogr. Reg. Plann. 2010, 3, 106-113. Available online: https:/ / academicjournals.org/journal/JGRP/article-abstract/5DEAA5539644 (accessed on 6 January 2018).

38. Jibril, I.U. Planning and Land Administration Challenges in Developing New Cities: The Abuja Experience in Nigeria. In Proceedings of the FIG Working Week, Sofia, Bulgaria, 17-21 May 2015.

39. Aliyu, R. Designing for Sustainable Communities: The Abuja Federal Capital Territory of Nigeria. Ph.D. Thesis, De Montfort University Leicester, Leicester, UK, June 2016.

40. Jelili, M.O.; Adedibu, A.A.; Egunjobi, L. Regional Development Planning in Nigeria: The General and Particular. J. Soc. Sci. 2008, 16, 135-140. [CrossRef]

41. Usman, I.J. An evaluation of the influence of Land-Use/Cover Change on the Surface Temperature of Federal Capital City (Abuja) Using Remote Sensing and GIS. Master's Thesis, Ahmadu Bello University Zaria, Zaria, Nigeria, February 2014.

42. Edicha, J.A.; Mgbanyi, L.L.O. Assessment of soil structural stability under different vegetal cover conditions in the Federal Capital Territory, Abuja, Nigeria. Niger. Geogr. J. 2013, 9, 110-121. Available online: https: / / www.researchgate.net/publication/274384618 (accessed on 22 December 2017).

43. USGS (United States Geological Survey). Available online: https://earthexplorer.usgs.gov (accessed on 10 June 2017).

44. AGIS (Abuja Geographic Information Systems). FCT Regional Plan 2000: Proposed Landuse; AGIS: Abuja, Nigeria, 2007.

45. Fola Consult Ltd. Federal Capital City: Revised Land Use Plan-2011 Phases I, II E III; Federal Capital Development Authority: Abuja, Nigeria, 2011.

46. Campbell, J.B.; Wynne, R.H. Introduction to Remote Sensing, 5th ed.; The Guilford Press: New York, NY, USA, 2011.

47. Lu, D.; Weng, Q.; Moran, E.; Li, G.; Hetrick, S. Remote Sensing Image Classification. In Advances in Environmental Remote Sensing: Sensors, Algorithms, and Applications, 1st ed.; Weng, Q., Ed.; Tailor \& Francis Group: Boca Raton, FL, USA, 2011; pp. 219-240. ISBN 978-1-4200-9175-5.

48. Tso, B.; Mather, P.M. Classification Methods for Remotely Sensed Data, 2nd ed.; Taylor \& Francis Group, LLC: Boca Raton, FL, USA, 2009; ISBN 978-1-42009072-7.

49. Ganasri, B.P.; Dwarakish, G.S. Study of land use/land cover dynamics through classification algorithms for Harangi catchment area, Karnataka State, INDIA. Aquat. Procedia 2015, 4, 1413-1420. [CrossRef]

50. Olofsson, P.; Foody, G.M.; Herold, M.; Stehman, S.V.; Woodcock, C.E.; Wulder, M.A. Good practices for estimating area and assessing accuracy of land change. Remote Sens. Environ. 2014, 148, 42-57. [CrossRef]

51. Yang, X. Integration of Remote Sensing with GIS for Urban Growth Characterization. In Geospatial Analysis and Modelling of Urban Structure and Dynamics, 1st ed.; Jiang, B., Yao, X., Eds.; Springer Science + Business Media B.V.: New York, NY, USA, 2010; pp. 223-250. ISBN 978-90-481-8571-9.

52. Elagouz, M.H.; Abou-Shleel, S.M.; Belal, A.A.; El-Mohandes, M.A. Detection of land use/cover change in Egyptian Nile Delta using remote sensing. Egypt. J. Remote Sens. Space Sci. 2019. [CrossRef]

53. Shen, X.; Wang, X.; Zhang, Z.; Lu, Z.; Lv, T. Evaluating the effectiveness of land use plans in containing urban expansion: An integrated view. Land Use Policy 2019, 80, 205-213. [CrossRef]

54. Hassan, M.M. Monitoring land use/land cover change, urban growth dynamics and landscape pattern analysis in five fastest urbanized cities in Bangladesh. Remote Sens. Appl. Soc. Environ. 2017, 7, 69-83. [CrossRef]

55. Gottdiener, M.; Budd, L.; Lehtovuori, P. Key Concepts in Urban Studies; Saga Publications Ltd.: London, UK, 2016; ISBN 978-1-84920-198-8. 
56. Lall, S.V.; Henderson, V.J.; Venables, A.J. Africa's Cities: Opening Doors to the World; International Bank for Reconstruction and Development/The World Bank: Washington, DC, USA, 2017; pp. 1-162. ISBN 978-1-4648-1044-2.

57. Zubair, O.A.; Ojigi, L.M.; Mbih, R.A. Urbanization: A Catalyst for the Emergence of Squatter Settlements and Squalor in the Vicinities of the Federal Capital City of Nigeria. J. Sustain. Dev. 2015, 8, 134-148. [CrossRef]

58. Freire, M.O.; Lall, S.; Leipzige, D. Africa's Urbanization: Challenges and Opportunities; Working Paper No. 7; The Growth Dialogue: Washington, DC, USA, 2014; pp. 1-30.

59. Trefon, T. Hings and fringes: Conceptualising the peri-urban in Central Africa. In African Cities: Completing Claims on Urban Spaces, 1st ed.; Locatelli, F., Nugent, P., Eds.; Koninklijke Brill NV: Leiden, The Netherlands, 2009; Volume 3, pp. 15-36. ISBN 9789047442486.

60. Goodfellow, T. Planning and development regulation amid rapid urban growth: Explaining divergent trajectories in Africa. Geoforum 2013, 48, 83-93. [CrossRef]

61. Barry, M.; Danso, E.K. Tenure security, land registration and customary tenure in a peri-urban Accra community. Land Use Policy 2014, 39, 358-365. [CrossRef]

(C) 2019 by the authors. Licensee MDPI, Basel, Switzerland. This article is an open access article distributed under the terms and conditions of the Creative Commons Attribution (CC BY) license (http:/ / creativecommons.org/licenses/by/4.0/). 